\title{
The Cultivation of Students' Interest in Learning for Primary School English Teaching
}

\author{
Zhang Yao \\ Ji Xiang Road Primary School, Xi’an, Shaanxi Province, China, 710061
}

Keywords: Primary School English; Learning Interest; Training Interest

\begin{abstract}
Primary school English is the enlightenment education of students' English. It is a very important lesson for students. Cultivating pupils' interest in learning English can not only improve the efficiency of primary school English teaching, but also lay a solid foundation for students to learn English in the future. Therefore, in the primary school English teaching, teachers should cultivate students' interest in English learning purpose, motivate students to actively participate in teaching activities, and fully mobilize the enthusiasm of the students, so that students learn in blending music. Based on the analysis and Research on the disadvantages of English Teaching in primary schools, this paper discusses some strategies to help students develop their interest in English learning.

Introduction: the students are in the development stage of the brain, noticing the time duration is short, the classroom can not concentrate on a long time, only to fully mobilize the enthusiasm of the students learning and promote students to actively participate in classroom activities to improve the efficiency of students learning english. In the course of teaching, teachers should not only teach primary school students English knowledge, but also cultivate pupils' interest in learning English consciously and improve their enthusiasm for learning english. In the best teacher, only primary school students have a strong thirst for knowledge of English, English Teaching in order to achieve a multiplier effect.
\end{abstract}

\section{The reasons that affect pupils' interest in learning English}

The pupils lived in native language, our native language is Chinese and English, which belongs to the Latin, the language structure and pronunciation and grammar are all be quite different with our native language for beginners of English, the students, is very difficult to understand and master. Especially in the memory and recite the words in the text are difficult, grammar learning is more difficult, in the course of time, students self-confidence in learning English has been hit, produce psychological resistance to learning English, not interested in active learning.

The traditional mode of teaching is the teachers to impart knowledge on the platform, and the students on the platform under the passive acceptance of knowledge, the attention to short duration pupils, dull and unable to concentrate on his study, the primary school students' interest in learning English gradually decreased, no lift force for learning [1]. Leading students English scores decline, hit the pupils to learn English and eventually lead to vicious spiral, pupils' English grades have a great psychological resistance to learning English, but also not conducive to the future of English learning. Therefore, in English teaching students, teachers should adopt appropriate teaching methods to guide students autonomous learning, help students to improve English learning interest, we can effectively improve the students' English achievement.

\section{The creation of classroom scenarios, training students' English-learning interest}

As a language, English is a tool for people to communicate with each other in daily life. It is closely related to people's daily life. It is not the topic of words and grammar. If you simply learn English as a memorized word and grammar on your test paper, you will soon lose your interest in 
learning English. [2]. Therefore, in the process of teaching, teachers should avoid the students of the English exam has just to create impression, but should be related to their life situations, so that students in the English language environment for learning English. The use of some real things between English and the students closer to the textbook, abstract, boring English words into a specific image with the real students can stimulate students' interest in learning greatly, and promote the students into active to English learning. For example, in PEP primary school English on the fourth grade in "my classroom" this lesson, teachers can lead the students at their own classroom, the text mentioned in the real use of English words to the students, the use of This is _ syntax to guide students with correct English pronunciation of spoken words. This not only creates the English language environment, but also helps students memorize words in a strong thirst for knowledge.

With the development of science and technology, more and more information technology has been applied to education and teaching. The use of multimedia means to produce some pictures, videos and other teaching materials related to classroom teaching, not only can enliven the classroom atmosphere, stimulate students' interest in learning, but also broaden the horizons of students. In the primary school English classroom, teachers can be appropriate with some related teaching contents of small video, movie clips, cartoons and other teaching materials, to provide students with an authentic English language environment, and stimulate students' enthusiasm for learning, so that students will learn to combine fun. This kind of teaching method breaks the dull teaching atmosphere, arouses the student's sensory stimulation fully, and enables the student to accept the teaching information which the teacher transmits. These teaching methods of multimedia teaching material the dull words, difficult grammar using animation and sound into the students' interest in the vivid video, animation and so on, in such a learning environment, whether intentionally or unintentionally students pay attention to pay attention to accumulate rich English knowledge and English language experience, made a good learning effect. For example, in PEP primary school English the fourth grade book "my home" this lesson teaching process, teachers can capture video clips some English TV shows to get home down, not only enrich the teaching contents, active classroom atmosphere, and to provide students with a pure English language environment. In such a language environment, students can better learn English knowledge to practice oral English.

Primary school children are still in a playful childhood, keen on play and games. In English teaching, teachers in different age students according to the textbook contents and teaching contents and create some age to match the characteristics of the game, not only can the active atmosphere, and concentrated energy pupils learn in blending music, so that students in a relaxed atmosphere of the game to learn English knowledge, cultivate students for learning interest the new language, based on [3] solid future learning and lay. At the same time, this teaching method can also enhance communication between teachers and students and between students and students, give students a platform to speak English, stimulate students' language expression of desire in the game, so that students express themselves, not only exercise the students pronunciation, and can help students accumulate knowledge of English language, so as to improve the teaching efficiency of the primary school English classroom teaching. For example, in person to teach the fifth grade primary school English textbook Unit version 3 "What would you like?" this lesson, the teacher according to the teaching contents, make a small game, let the pupils were playing different roles, to deduce the text, a student asked: "What would you like to eat?" other students according to the teaching content to choose their own food or drink love in order to answer: "I" d like_ "in English, and the simple explanation has learned a reason to choose such food. In such a small game of text reproduction, students can have a deep understanding of and grasp the fixed sentence patterns, and stimulate the students' desire to express themselves, and guide them to speak English.

Music is the most wonderful thing in the world. The pupils have an instinctive desire for music, in the process of teaching, teachers can teach the students according to the teaching contents of some sung high degree, is easy to learn English songs in English songs, let students experience the fun of learning English and foreign language culture. Some strong ability of teachers can also be 
difficult to understand and recite the text into the pupils for having heard it many times the song, not only can stimulate the atmosphere of the classroom teaching, cultivate students' interest in learning, but also can deepen students understanding of English knowledge, classroom teaching has a multiplier effect. For example, in the process of teaching, a teacher can sing the first sentence of a simple English song at random, so that the students can go on and on, and let the whole teaching begin in the harmonious atmosphere of music[2].

\section{The use of encouraging mechanisms to develop primary school students' English-learning interest}

In the traditional teaching mode, teachers are the main body of the class, students only played a passive role, especially in the primary school education, teachers not only impart knowledge played a role, but play a role of parents, so the pupils do not meet the standard behavior of severe criticism. The primary school is an important period of mental development, many pupils easily reverse psychology in the face of the teacher's criticism, and the weariness of negative emotions, resulting in lower scores, the students learning life have an extremely negative impact. Especially in the process of teaching English in primary school, primary school due to the initial contact an irrelevant to their language learning, inevitably a lot of mistakes, if received harsh criticism of the teacher, it is easy to lose confidence and interest in English learning, resulting in English performance decline, serious impact on the future of English continue to learn. Therefore, in the process of developing primary school English learning interest, teachers must adopt more encouraging mechanism for primary school students[3].

In the classroom teaching, teachers often before the class for the class about knowledge review or speak to the class in the classroom before the end of this time, summarize the knowledge, teachers can design some concluding the key or difficult knowledge questions for students. When students answer questions, teachers should listen carefully, and timely give students encourage eyes and smile, let the students realize their ideas have been expressed by the teacher to understand, when students answer correctly, the teacher should not mean to give them praise, but also to encourage the students to lead other applause, not only to active classroom atmosphere, but also can enhance their self-confidence and pride; and when the student's answer is not satisfactory, the teacher also don't criticize, do not immediately pointed out the problems in the student's answer, but the first on the student's response to a part of the affirmative, then put forward some corrections or suggestions for the more perfect. This approach can improve the students learning English to meet in a large extent, let the students to learn English is full of confidence, with the confidence to be able to make students cultivate interest in learning English, and active in learning english. For example, in the pre class preparation, teachers can make students will last lesson learned the text read aloud, when students read after the teacher first dealing with students' courage and enthusiasm expressed praise, and one of the more standard pronunciation and sentence more smoothly apprieciate, finally according to the students' individual put forward some suggestions for improvement of the recitation, finally led the class of students with applause encouragement. Such encouragement way can effectively improve the pupils' confidence in learning, let students have the courage to speak English, don't be afraid of making mistakes, and finally lead all students to actively participate in the organization of teachers in classroom activities, greatly cultivate the students'interest in oral English learning[4].

English is a language tool. The best way to learn English is not to memorize it, but to translate the acquired knowledge quickly into practical use in life. In the classroom, the teacher can give the student a certain amount of time to divide the students into groups and communicate in english. The English can be put in before class, review of the section on the teaching content or introduce the lesson, can also be placed in class, put forward some different opinions on the text, vocabulary and grammar, can also be placed in the end of the class, for the lesson summary. For example, in the end who taught Unit the fifth grade primary school English textbook version 6 "In a nature park" in this class, teachers can put the students in small groups to introduce their own side of the park to make himself the most impressive scenery to each other in English, at the end of each group chooses a 
representative summary group I speak not only to promote the communication between students and students of English, but also promote the communication between students and teachers of English, the teacher comments and encouragement for each team, effectively enhanced the classroom atmosphere, cultivate the young students' interest in learning English, stimulate the initiative of students learning english[5].

In primary school English classroom, teachers should take the initiative to give the students the classroom, create a relaxed and pleasant learning atmosphere for students, teachers can according to the specific circumstances of the students in teaching guidance for students, leading students to independent thinking, thinking in the classroom of the key and difficult points of knowledge of English encourage students to think for themselves, to explore the methods of learning English, feel the charm of the language independent and broad and profound, deepen understanding of english. In the process of thinking, students continue to accumulate their own experience in learning English, teachers should actively encourage students at their own experience to the flexible use of English learning, so that students have their own initiative to learn and satisfaction at the same time, more on learning English has been of increasing interest. In order to produce a virtuous cycle, interest driven learning, learning interest, make students learning English easier and more efficient[6].

\section{Conclusion}

Primary school students' English learning is an enlightening classroom for students to learn English. It not only shoulders the important task of laying a good foundation for primary school students to learn English, but also lays the foundation for learning other languages in the future. Therefore, in English teaching, teachers should pay attention to teaching methods and strategies, to provide students a pleasant teaching atmosphere, teaching methods are more rich and colorful in the age of students, in the teaching process for students should be encouraged to give praise and timely, so as to fundamentally make the students learning English learning in music, effectively training the students' interest in learning english.

\section{References}

[1] Penney D. The effects of setting on classroom teaching and student learning in mainstream mathematics, English and science lessons: a critical review of the literature in England[J]. Educational Review, 2014, 66(4):411-427.

[2] Eren A. Prospective Teachers' Interest in Teaching, Professional Plans about Teaching and Career Choice Satisfaction: A Relevant Framework?.[J]. Australian Journal of Education, 2012, 56(3):303-318.

[3] Forbes A, Skamp K. Secondary Science Teachers' and Students’ Involvement in a Primary School Community of Science Practice: How It Changed Their Practices and Interest in Science[J]. Research in Science Education, 2016, 46(1):91-112.

[4] Chan L I, Polytechnic L. Research on the Methods of Cultivation of Students' Interest in Learning the Piano Teaching System of Preschool Education Specialty[J]. Journal of Hubei Correspondence University, 2017.

[5] Zhou X M. Applying Games Teaching Approach to Improve Primary School Students' Interest in English[J]. Journal of Fujian Institute of Education, 2007.

[6] Peng Z H. Discussion on the cultivation of students' interest in English teaching[J]. 